\title{
Physical Qualities and Elements of Streets in the Context of Royal Town in Malaysia
}

\author{
Wan Norisma Wan Ismail ${ }^{1,2}$, Nor Haslina Ja'afar², Nor Zalina Harun² \\ ${ }^{1}$ Department of Architecture, Faculty of Engineering and Built Environment,Universiti Sains \\ Islam Malaysia.Email: norisma@usim.edu.my \\ ${ }^{2}$ Centre of Architecture and Built Environment Innovative (SeRAMBI), Programme \\ Architecture, Secretariat of Identity of National Architecture, Faculty of Engineering \\ and Built Environment, Universiti Kebangsaan Malaysia
}

\begin{abstract}
Streets are the basic elements in the urban structure and it characterized the townscape and image of the town. The street provides a link between buildings, both within the street, and in the town at large. Streets and buildings must be appropriate to, and unique to, the particular town in which they are located. This article is based on the findings of a doctoral research examining characteristics of street from the aspect of building appearance in the royal town of Kuala Kangsar. Mixed methodology approached are adopted using the triangulation design through the combination of quantitative data with qualitative data to further analyze the relations between them and subsequently validated by focus group discussions. The study found that building is a key component that forms the character of a street and it is contributed by physical qualities such as attractiveness,visibility and human scale. These physical qualities are contributed by physical elements namely building design, building skyline, building continuity and consistency, vertical elements, appearance of civic building, marker sequences, building scale and enclosure. While each of these elements are influenced by factors such as building location,building function, building age, building height and size, building form, building openings, roof form, architectural style, facade treatment and decorations, building signage, street width, five-foot walkway and quality of view. The paper concludes by establishing that street characteristics has a significant contribution in preserving the identity of the royal town therefore it should be consideredfor the improvement and refinement of existing guidelines regarding the physical design of streets in the royal towns of Malaysia.
\end{abstract}

Keywords: Street, character, royal, town, physical, elements, qualities.

\section{Introduction}

Streets embody the most basic element of a town's spatial structure. Streets are the reflection of every town's image and identity. The pattern of the street network adds to the definition of the town and it also makes each town unique (Desai 2015). Streets constitute a significant part of open public space and are the most important symbols of the public realm (Mehta 2007). Good street design with a strong sense of local identity is much more likely if the roots of character are recognized in the urban structure of the royal town. Places that grow true to their locality are likely to be sustainable therefore an appreciation of local climate, culture, topography and physical structures particularly its building appearance is necessary to nurture local distinctiveness. Historic townscape of major towns including royal towns in Malaysia is considered unique if compared to newer counterparts due to the significant difference in character in the form of architecture and

(C) AesthetixMS 2020. This Open Access article is published under a Creative Commons Attribution Non-Commercial 4.0 International License (http://creativecommons.org/licenses/by-nc/4.0/), which permits non-commercial re-use, distribution, and reproduction in any medium, provided the original work is properly cited. For citation use the DOI. For commercial re-use, please contact editor@rupkatha.com. 
street design. According to Shamsuddin (2011), the sense of variety within uniformity is one of its strong features that make the historic town different and having a stronger sense of place. Therefore, this paper highlights physical qualities and elements of street characteristics and its significance in preserving the identity of the royal towns in Malaysia.

\section{Background and Issues}

Streets as public space are often overlooked. When planning a town, the multiple functions of street are poorly integrated and, in worst case, are neglected (Mboup, G. 2015). Studies by Ja'afar (2014), Sulaiman \& Shamsuddin (2010) and Shamsuddin (1997) found that rapid development and urbanization in Malaysia have a significant impact on the functioning of streets as open public spaces. Development towards of a more modern town has contributed to a great loss of streets significance as spaces for socializing and dwelling in the local people's needs (Ab Rahman et al 2019). Shukri et al. $(2018,2017)$ and Harun et al. (2015) revealed that extensive development growth occurring in most historical towns have significantly eroded the identity, sense of place and physical attributes of the Malay royal town in Malaysia. Harun \& Said (2015) argued that large-scale development has further diminished the importance of the royal town which is rich in historical and cultural values that should be preserved. Samsudin et al. (2018) stated that the existence of royal towns in Malaysia is essential to preserving its heritage identity but would be lost throughout time without any proper actions taken to protect this priceless historical value.For a town rich in history and heritage buildings such as the royal town of Kuala Kangsar, the importance of strengthening the image and identity of the town should be emphasized in order to preserve its heritage that can only be found in towns associated with the Malay Sultanate (Fauziah et al. 2014). This shows that physical characteristics in royal townhas a significant impact on the value and identity of places associated with the history of the place. Thus, a study to identify the character of the street that contributes to the sustainability of the town is important to strengthen the image and identity of the place.

\section{The Context of the Study}

The study area involves Zone A covering Jalan Istana and Zone B covering both Jalan Laksamana and Jalan Shahbandar, located in the royal town of Kuala Kangsar, Perak. A comparative analysis study of each royal town in Malaysia was conducted to justify why Kuala Kangsar was chosen as the case study for this research. Factors that have influenced the selection of Kuala Kangsar are, firstly, Kuala Kangsar is the oldest royal town based on the crowning of the first Sultan of Perak in 1528 (Lubis et al 2010, Selamat \& Othman 2016) in which a town would only be made a royal town in the presence of a Sultan of the respective states. Secondly, its official declaration of being the first official royal city compared to other states was in 1887 by Sultan Idris Shah I (Selamat \& Othman 2010). Thirdly, the location of this royal town remains to this day without changing its location as some other royal towns in Malaysia which then resulting in the loss of the identity of the place. Lastly, the town has 26 heritage buildings that have been gazetted by the National Heritage Department, significant to its development as a royal town that is rich in urban heritage assets (Local Plan Kuala Kangsar District 2020). Meanwhile, Istana Street was chosen based on its function as the Protocol Street and Civic Street with formal characteristics as well as street functions that often involves various official royal activities. Several important civic buildings including royal buildings such as royal palaces, royal mosques and royal museums dominated the route along this street. Laksamana Street and Shahbandar Street were chosen for their functions as Commercial 
Streets and Combination Street. This is due to the presence of commercial buildings and mixeduse buildings (old shophouses) along the street, which depict the street as a public space that forms the distinctive image and identity of the royal town. Streets with different typologies (civic street, commercial street and combination street) enriches the results as it encompasses a comprehensive study between the appearance of the buildings and its related street.

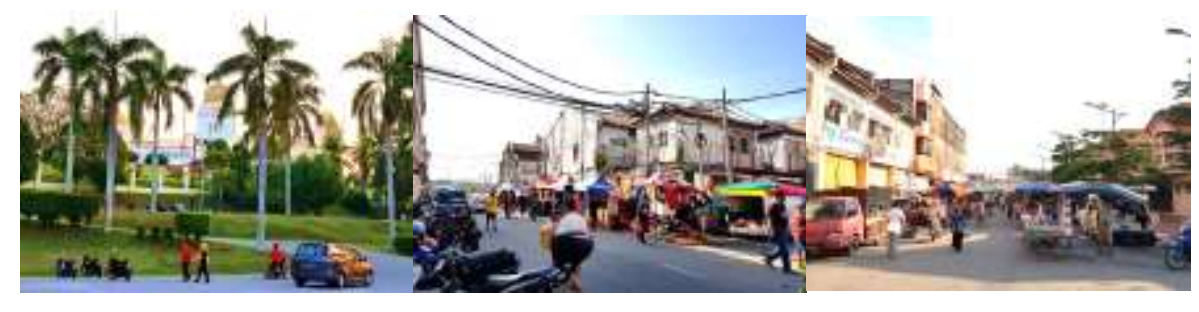

(a)

(b)

(c)

Figure 1: General views of Istana Street (a), Laksamana Street (b) and Shahbandar Street (c)

\section{Methodology}

This research involves a mixed method approach where analysis was done on both the qualitative and quantitative data. The quantitative method used the 330 questionnaire surveys with a sampling error of 5.5\% at 95\% confidence level, which are employed by many considerable researchers (AlObeidy \& Ali 2017; Ja'afar 2014, Shamsuddin et al 2004, W Ismail 2009, Ujang 2008, Ja'afar 2006, DeVaus 2002, Appleyard 1980, Shamsuddin 1997). From the response of the survey, these data were re-measured using the qualitative method which included $21 \mathrm{semi}$-structured in-depth interviews, field observation and cross-examined by historical document analysis techniques. The field observations record and appraise the characteristics of the physical elements noticed and the activities that dominated the scene while the in-depth interview investigates the influence of each elements towards achieving the physical qualities that contribute to the character of the streets of the royal town. The data were processed and tabulated using both qualitative and quantitative approaches through a triangulation method and cross analysis between different techniqus as well as literature review to find potential patterns and facilitate comparisons and relations between them.

\section{Components, Elements and Qualities Influencing Street Character}

The physical components and elements that contribute to the physical qualities create a significant sense of place that influences the character of a street. Building is the most important component associated with street character for the streets studied due to its physical appearance and functions of the streets. The success of the streets is influenced by the ability of places to affectively accommodate human activity (Shamsuddin \& Ujang 2008). It also appears that places stimulating many activities form a lively street (Moughtin 2003) while Lynch (1960) states that concentration of activity along a street may give it prominence in the minds of observers which make places and streets memorable. Attractiveness, visibility and human scale were identified as significant qualities of building's appearance contributing to the character of street as shown in the summary (Table 1) and findings of the study as discussed below:

Table 1:Summary of qualities and elements based on appearance of building

\begin{tabular}{cccc}
\hline Qualities & Attractiveness & Visibility & Human Scale \\
\hline Elements & Building Design & Vertical Elements & Building Scale \\
\hline
\end{tabular}




\begin{tabular}{|c|c|c|c|}
\hline & $\begin{array}{c}\text { Building Skyline } \\
\text { Building Continuity and } \\
\text { Consistency }\end{array}$ & $\begin{array}{l}\text { Civic Buildings } \\
\text { Marker Sequences }\end{array}$ & Enclosure \\
\hline & $\begin{array}{c}\text { Location of Building } \\
\text { Building Function } \\
\text { Building Age } \\
\text { Architectural Style } \\
\text { Facade Treatment and } \\
\text { Decorations } \\
\text { Building Signage } \\
\text { Quality of View }\end{array}$ & $\begin{array}{l}\text { Location of Building } \\
\text { Building Function } \\
\text { Building Height and Size } \\
\text { Building Age } \\
\text { Building Form } \\
\text { Roof Form } \\
\text { Architectural Style } \\
\text { Quality of View }\end{array}$ & $\begin{array}{l}\text { Building Function } \\
\text { Building Opening } \\
\text { Building Length } \\
\text { Five Foot Walkway } \\
\text { Street Width } \\
\text { Building Height }\end{array}$ \\
\hline Techniques & \multicolumn{3}{|c|}{$\begin{array}{c}\text { Observation, In-depth Interview, Document Analysis, Questionaire Survey, Focus } \\
\text { Group Discussion }\end{array}$} \\
\hline
\end{tabular}

\section{Result and Discussion - Physical Qualities and Elements Associated with Building Appearance}

\section{a. Attractiveness}

Building Design - The result shows that the architectural design of the buildings contributing to the attractiveness of the street is associated with the distinctive appearance of the buildings along the streets. The survey shows that all respondents $(n=330)$ found that the buildings along the streets are attractive. This finding was also supported by all respondents $(n=21)$ through in-depth interviews. Meanwhile, questionnaires and interviews indicating the most attractive buildings around Zones A and B are listed in Table 2 and its location is shown in Figure 2.

Table 2:Attractive buildings mentioned by respondents in describing the building appearance

\begin{tabular}{|c|c|c|c|c|}
\hline \multirow{2}{*}{ Building } & \multicolumn{2}{|c|}{ Questionaire $(n=330)$} & \multicolumn{2}{|c|}{ In-depth Interview $(\mathrm{n}=\mathbf{2 1})$} \\
\hline & Frequency & $\%$ & Yes & No \\
\hline \multicolumn{5}{|l|}{ ZONE A (Istana Street) } \\
\hline Iskandariah Palace & 325 & 98.4 & 21 & - \\
\hline Ubudiah Royal Mosque & 300 & 90.9 & 21 & - \\
\hline Perak Royal Museum & 280 & 84.8 & 20 & 1 \\
\hline Sultan Azlan Shah Gallery & 255 & $77 \cdot 3$ & 18 & 3 \\
\hline Colonial Houses & 96 & 29.1 & 11 & 10 \\
\hline Traditional Malay Houses & 78 & 23.6 & 7 & 14 \\
\hline \multicolumn{5}{|c|}{ ZONE B (Laksamana \& Shahbandar Street) } \\
\hline Old Shophouses & 89 & 26.9 & 9 & 12 \\
\hline Commercial Buildings & 36 & 10.9 & 4 & 17 \\
\hline
\end{tabular}




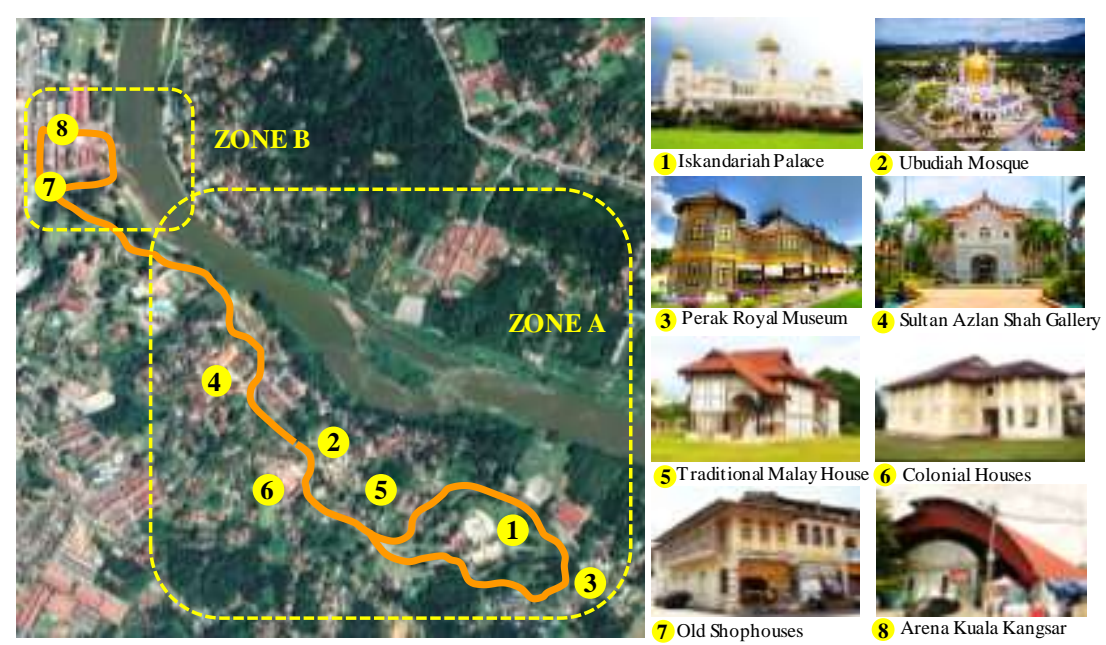

Figure 2: Map showing location of buildings

Results shown in Table 2 indicate that respondents associated attractiveness with several important elements. Firstly, location of the buildings on a hilly area around Chandan Hill (Iskandariah Palace 98.4\%, Ubudiah Mosque 90.9\%, Perak Royal Museum 84.8\%, Sultan Azlan Shah Gallery 77.3\%) contributes to the distinctive architectural appearance of the civic buildings. Its location along the Perak River also creates an impressive quality of view from the top down and makes it easily recognizable from afar. Secondly, the function of Iskandariah Palace as the most dominant civic building which serves as the adminisrative centre for the state of Perak Sultanate and the Ubudiah Mosque as a visual symbol of the presence of Islam emphasize the functionality of these two most prominent civic buildings.

The analysis also found that the architectural style and details of the building are strongly related to the age and history of the building. This is evidenced by historical documents that the 86 year old palace and 102 year old mosque which was both gazatted as heritage buildings has an attractive and unique architecture design where both architectural details resembles the Islamic Indo-Saracenic style blended with the architectural style of West Asia. Meanwhile, the 116 year old Sultan Azlan Shah Gallery which was reconstructed from the old Istana Ulu combines Moorish, Acheh and Indian architectural styles are loaded with meranti wood carvings details. The 93 year old Perak Royal Museum which was remodelled and converted from the Istana Kenangan represents the impressive Malay architecture embellished with intricate carvings of traditional patterns (Kuala Kangsar District RT Research 2020, Department of National Heritage 2010, National Archives of Malaysia). Finally, the old shophouses in Zone B is listed as the most attractive building. Analysis indicates that percentage of the questionnaire (26.9\%) and responses of 9 respondents $(n=9)$ through in-depth interviews were associated with the use of a dual-function two-storey old shophouse (commercial use downstairs and residentail use upstairs). Rows of oldshop house incorporating rich colonial architectural style with unique building details and western décor accentuates its physical appearance.

Referring to the analysis of discussions in both Zones A and B, it is concluded that suitabilitof the location, functionality of the building, diversity of architectural styles and unique building details and the presence of old buildings that are significant to the history of the place are elements resulting to good quality of views. The analysis revealed that building appearance is associated with the quality of attraction for the streets of royal town, the oldest royal town lined with old historic buildings highlighting the sense of place. This is in line with the opinion of Venturi et al. (1986) and Sulaiman (2000) that the appearance and physical condition of a building affects 
the quality of attractiveness especially in old town with distincive buildings and attractive streetscape. These elements highlight the image and identity of the place which further contributes to the character of the streets in the royal town.

Building Skyline - Elements that contribute to the quality of the building's skyline based on the research techniques are associated with the height of the building, shape and size of the roof, building location, building function and the quality of view. The survey recorded $93.6 \%(\mathrm{n}=309)$ respondents agree that attractiveness was contributed by factors such as location, height, shape and size of roof which subsequently formed an attractive streetscape. While $86.4 \%(n=285)$ of the respondents found that building function, building age and quality of view also influenced the building's skyline. This finding was also supported by all respondents $(n=21)$ for each element based on in-depth interviews. Through observations in Zone A, the building's skyline is derived from the functioning of the civic buildings namely the Iskandariah Palace, Ubudiah Mosque and the Sultan Azlan Shah Gallery and their strategic locations that are arranged in a series along the contours of Chandan Hill. Different height measurements between these civic buildings are associated with the presence of large roof sizes with unique shapes and prominent towers and minarets. Measurements found that the $99 \mathrm{~m}$ long $\mathrm{x} 38.7 \mathrm{~m}$ width rectangular shaped palace has two onion-shaped main domes and eight onion-shaped smaller ones located at each corner of the palace. While the $45 \mathrm{~m}$ high Ubudiah Mosque is also decorated with an onion-shaped main dome rising to a height of $42.7 \mathrm{~m}$ tall and surrounded by four minarets, each topped with a chhatri and a small dome, $38.4 \mathrm{~m}$ in height and 16 turrets. Meanwhile the Sultan Azlan Shah Gallery has a 22m high tower and is adorned with a turquoise-colored two-storey domed roof.

Meanwhile findings in Zone B found that the location of the mixed-use buildings on a flat ground resulted in a less attractive streetscapes than the hilly terrain. Apart from that, the presence of old shophouse with various heights influenced the rhythm and pattern of the building as well as the overall skyline. Observations revealed that this was due to uncontrolled renovation work. It is found that most of the $6 \mathrm{~m}$ high two-storey old shop houses have been refurbished to 3-6 floors (9$15 \mathrm{~m}$ ) and this has affected the building's skyline and resulted in less attractive streetscape. This is evident by an inventory record that $37.2 \%$ of shophouses involved in uncontrolled renovations affecting the existing building's skyline (Figure 3). Clearly, the imposition of a common roofline and the repetitive use of similar bay sizes are important to strengthen the unity in many street scenes (Moughtin 2003). This study demonstrates that building location, building height, shapes and sizes of roof and the presence of towers and minarets has created an attractive building skyline which makes it visible from various directions. Therefore, new/refurbished development should consider the impact on the building's skyline from all angles but at the same time maintain its attractiveness. 


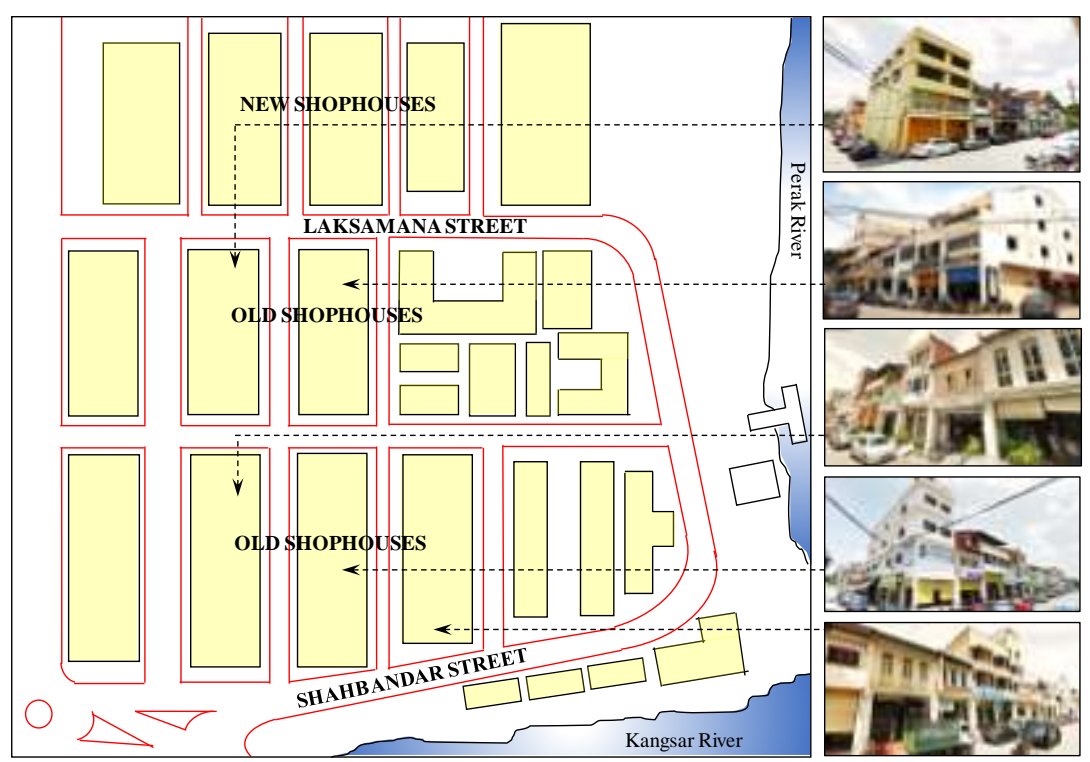

Figure 3: Various building heights affects the uniformity of the roofscape and building skyline along Laksamana Street and Shahbandar Street

\section{Building Continuity and Consistency}

Continuity of Building Façade -Results of the survey recorded $80.9 \%$ ( $n=267)$ respondent indicated that continuous facade design is associated with the quality of attractiveness along the streets and this finding was also supported by 18 respondents $(n=18)$ through in-depth interviews. It was observed that continuity and consistency of the building facade's appearance is linked to the functioning of the old shophouses through its architectural style, uniformity of height, repetitive typical units, harmonious building lines and the buildings's horizontal and vertical articulation. This is based on inventory records showing that the number of old shophouses with continuious facade design is $40.5 \%(n=45)$ while the remaining $59.5 \%(n=66)$ displaying non-continuous facade designs. For shophouses that have undergone renovation process, it is found that almost all facades of the refurbished units are unresponsive to the original design that is rich in colonial-style ornamentation. The mixed combination of both colonial style (existing) and customization design without any particular architectural style (due to renovation) resulted to an imbalance design that further affects the entire rythm of the facade. Some of the shophouses units that ranged along Laksamana Street have varied forms, styles and treatment causing the space loses definition. It was also observed that this inconsistency was due to the varying height of the typical units (6-15m), lack of repetitive typical units to produce a balanced of rythm and pattern, unequal size and shape of openings as well as the absence of horizontal and vertical articulation that effects the building aesthetic value which subsequently resulted in an unattractive streetscape. To strenghten the unity of street scenes, the imposition of a common roofline and the repetitive use of typical bay sizes should be applied. The above discussion shows that these factors play an important role in contributing to a unified street design and attractive streetscape in the royal town. 


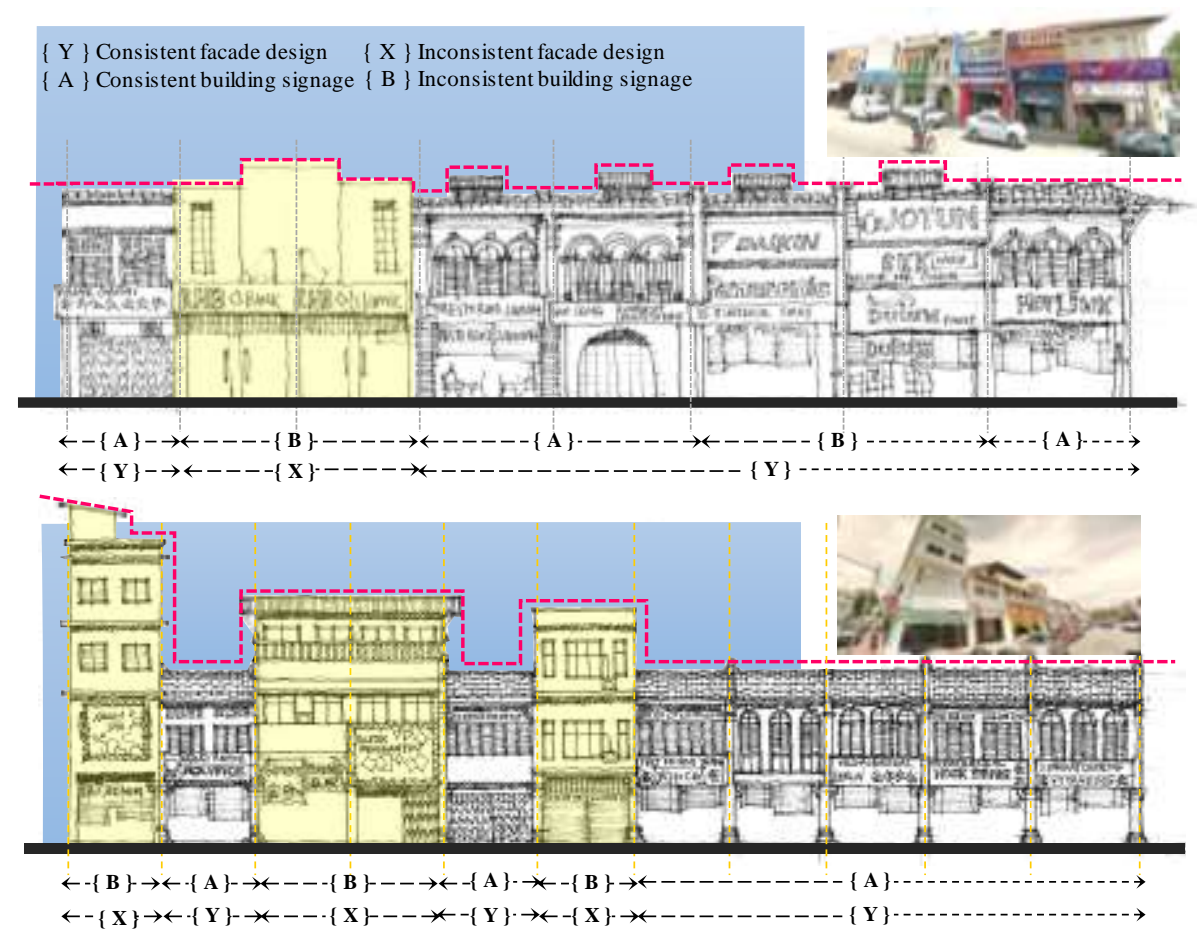

Figure 4: Overall appearance of the building facade - the shaded facade is inconsistent with the typical unit adjacent to it and this affects the attractiveness of streets in Zone $B$

Continuity of Building Signage -The survey shows that $75.8 \%(\mathrm{n}=250)$ respondent felt that building signage was also related with the appearance of a continuous building facade of the old shophouses. 16 respondents from in-depth interviews also supported this finding. Observation recorded that there are 126 building signages around Zone B. 62 (49.2\%) signages did not cover the building facade while $43(34.1 \%)$ signages covered almost the entire facade of the building. The remaining $21(16.7 \%)$ signages was recorded as a traditional design building signage. The small percentage difference (15\%) was significant because the continuity of the building facade that contributes to the attractiveness of the street is greatly influenced by the building signage. It was evident from the interviews ad observations that signage covering the building facade was due to its inappropriate location where it covers the surface of the front wall of the building and the size of signage was too large that it loses its human dimension or scale. Multiple signages in one place as well as excessive graphic design confuses pedestrians to recognize the streets. This makes the streetscape less attractive because the facade of the old shophouses is visually obstructed by the appearance of the unappropriate size, number, location and inconsistent building signage design (Figure 3).

It was also observed that signage with traditional design on which the inscription was engraved on the wall was more attractive as it did not obstruct the appearance of the building facade. It was evident from the observation that methods applied by the premises that still retains its traditional signage design is through (i) the name of the shop engraved on the wall surface of the front facade (ii) the name of the shop engraved on the front pillar of the building and (iii) the name of the shop inscribed on the bamboo blinds acts as barrier to sunlight. This shows that the adaptation of traditional signage design concepts through the above methods can be use as a reference to maintain the continuity of the building facade and thus contribute to the attractiveness of the street. 


\section{b. Visibility}

Vertical Elements - Results of the survey found that all respondents $(n=330)$ were able to identify the streets around the study area and this was also agreed by all respondents $(n=21)$ through indepth interviews. Respondents who identified these streets indicated that elements that make the street recognizable are important and that it contributes to the visibility of the streets. It was observed and supported by most of the interviewees that visibility around Zone A was associated with the functioning of the prominent civic buildings namely the Iskandariah Palace and Ubudiah Mosque and the presence of old and historic buildings (civic buildings and residential building). The presence of vertical elements such as the $42.6 \mathrm{~m}$ high tower at the palace and the $38.4 \mathrm{~m}$ high minarets of the mosque as well as the large building scaleenhanced visibility and subsequently formed landmarks. While in Zone B, the 13m-tall Kuala Kangsar Clock Tower located in the middle of the round about also elevates visibility and helps improve recognition levels thus forming a dominant point of reference (Figure 5). The finding highlights that the function of prominent civic buildings, the height of vertical structures through the presence of towers and minarets and suitability of its location facilitate visual recognition and acts as a reference point giving direction and position contributing towards a clear image of a street. This forms a more visible streetscape and contributes to the character of the streets in the royal town.

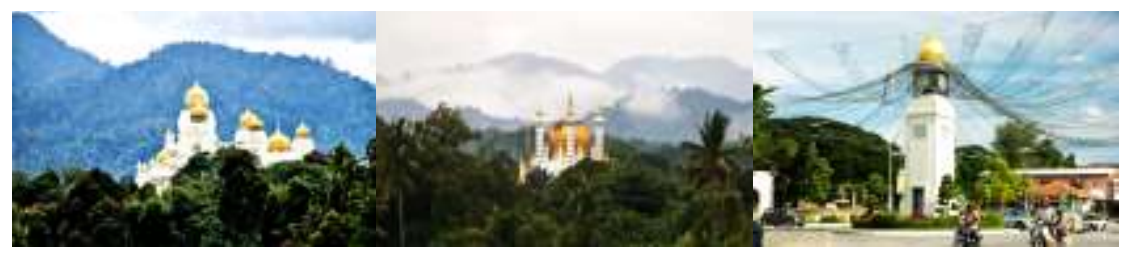

(i)

(ii)

(iii)

Figure 5: The presence of vertical elements from the tower of Iskandariah Mosque (i) the mineret of Ubudiah Mosque (ii)and the Kuala Kangsar Clock Tower (iii) enhances visibility and acts as a reference point and landmark to the Royal Town

Appearance of Civic Buildings-According to the survey, 91.5\% ( $n=302)$ respondents found that the appearance of civic building was associated with visibility and street recognition in the royal town and this percentage was also supported by all respondents $(n=21)$ through in-depth interviews. Observations have shown that royal-related buildings which highlights the functioning of the civic buildings namely the Iskandariah Palace, Ubudiah Mosque, Sultan Azlan Shah Gallery and Perak Royak Museum has created a series of landmarks that enhance the quality of visibility along Istana Street. The unique building shapes formed through a combination of several basic geometrical forms and adorned with prominent architectural styles also contributed to the appearance of these civic buildings which further enhanced the visibility of the street and its surroundings. Observations indicate that symmetrical building such as the Iskandariah Palace are formed from a combination of rectangular and square shapes while the combination of octagonal and rectangular shapes forms a very unique Mosque. The asymmetrical shape of the Sultan Azlan Shah Gallery is a combination of several rectangular shapes while the Perak Royal Museum has a unique shape where it looks like a sword in its scabbard if viewed from the top. The analysis revealed that the appearance of civic buildings in terms of the functionality of the buildings and uniqueness of the building shape allowing pedestrians to differenciate one street from another and this improves the quality of visibility which further contributes to the character of streets in the royal town of Kuala Kangsar.

Marker Sequences- The findings recorded 89.7\% $(n=296)$ respondents from the survey results and $19(n=19)$ respondents through in-depth interviews found that marker sequences were associated 
with visibility and street recognition in the royal town. Based on observations, for long and winding streets such as Istana Street, the presence of prominent civic buildings such as the Palace, Mosque and Gallery as additional markers at street corners formed a series of road markers that create visible and legible streets. The distinctive architectural style of these civic buildings serves as a visual landmark even in winding streets. The presence of buildings at the street corner acts as a guide to pedestrians about their location on a street. This helps them to visualize where they are even though they are not sure what is ahead of the winding street. This finding demonstrates the presence of civic buildings that highlight its function through the link between its location on the street and its architectural style that stands out from its surroundings. This subsequently formed sequence of markers that makes the street visible and create 'a sense of getting somewhere' to pedestrians. Thus, the relationship between the functioning of the civic buildings, architectural styles that stands out and the appropriateness of its location along the winding streets makes visibility possible. This forms a clear path through the physical appearance of the buildings that stand as markers which help make the street more visible, legible and recognizable.

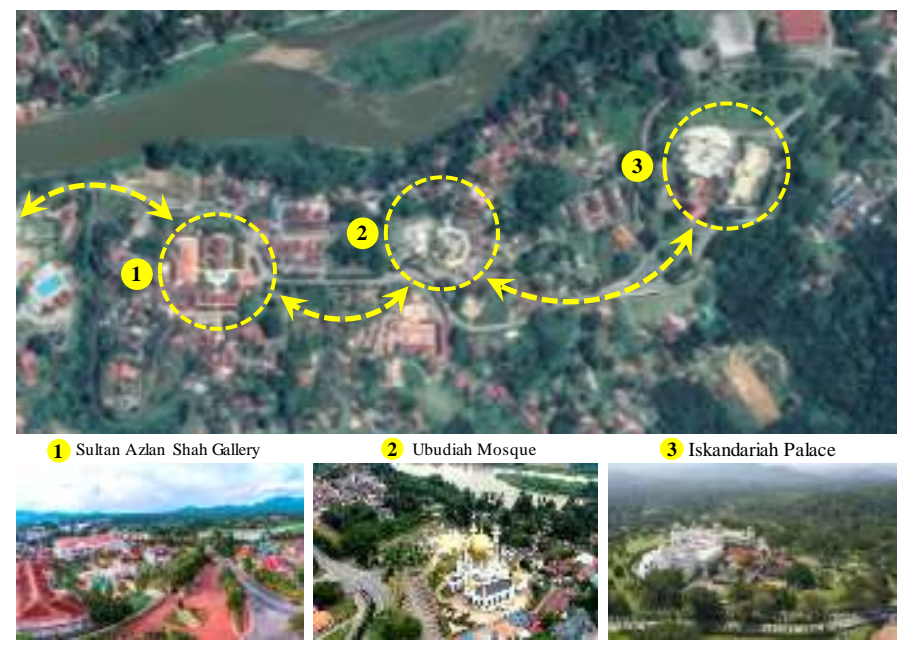

Figure 6: The presence of the palace, mosque and gallery along the winding street (Istana Street) formed a continuous visual chain of markers supporting visual permeability and legibility

\section{c. Human Scale}

Building Scale - The results of the in-depth interview recorded that 18 respondents $(n=18)$ found that function of the building, the width of the building frontage, the length of the building and the presence of five-foot walkway were associated with human scale. This opinion was supported by observations and measurements that there are several types of old shophouse designs, most of which were rectangular with narrow building width and extending to the rear of the building (e.g. $4 \mathrm{mx22m}$ ). The number of units per block is quite large, ranging from 11-13 units which makes the block lengths to be 44-52m long per block. This situation is similar to the principle of 'narrow units many doors' by Gehl (2011) where design with narrow and longitudinal frontages are highly recommended so that there is room for as many shops as possible in the shortest possible street distance. Through building scale that emphasizes these narrow and long unit designs that corresponds to the speed of human movement, it indirectly creates a human-scale street environment. Besides that, the survey also found that this principle creates junctions between blocks that are less than 10om. According to Moughtin et al (1999), if the distance of each junction between blocks is within the range of $70-100 \mathrm{~m}$, the comfort level for pedestrian movements will increase. Jacobs (1993) also states that streets with junctions at a distance of 300 feet (91m) improves accessibility and are often an example of a successful street design. 
Apart from that, interviews and observations also found that the presence of five-foot walkway with low ceiling heights along the blocks of old shop houses allows pedestrian to move around while shopping comfortably. It was evident from the observation that the $1500 \mathrm{~mm}$ wide walkway with an average height of $2500 \mathrm{~mm}$ is proportional to human scale as well as speed of movement for pedestrians. In conclusion, factors such as appropriate building scale, junctions between adjacent block and the presence of five-foot walkway that corresponds to human proportions contribute to the human-scale environment and a safe and comfortable street.

Enclosure -The survey found that most respondents $(65.2 \%, \mathrm{n}=215)$ agreed that narrow streets were associated with the presence of enclosure formed between streets and buildings. This finding was also supported by all respondents $(n=21)$ through in-depth interviews. Majority of the users perceived that the narrow streets flanked by old shophouses on both sides of the streets around Zone B (Laksamana Street and Shahbandar Street) formed an enclosed space and it became alive with the presence of activity around it. Through observations, it was clear that the sense-ofenclosure is felt more along the streets in Zone B than in Zone A as this area has higher density wih buildings arranged in a grid-shaped street pattern. Measurement records the size of Laksamana Street at $7 \mathrm{~m}$ wide and is flanked by shop houses of varying height between $6-15 \mathrm{~m}$ forming an enclosed space based on the ratio of the street width to the height of the building is $1: 2$ and this creates a viewpoint exceeding 45ㅇ. According to Carmona et al (2003), ratio between 1:2 and 1:2.5 provide a good sense-of-enclosure in a street where the peripheral glimpses of sky equal the amount of visual field devoted to the street wall. Whereas Sulaiman et al. (2007) state that sense-ofenclosure is highest when the visual angle between street width and building height is equal to or greater than $45^{\circ}$. It is evident that when streets are narrow and flanking buildings three or four storeys it gives the sense of completeness and enclosure to the pictures in the streets (Moughtin 2003).

Around Shahbandar Street, it was also observed that with the same street width (7m) but as it is only flanked by a row of shophouses therefore enclosure is not formed and there is no focal point of view despite pedestrian activity. Without a focused visual angle, the effect of enclosure on the street space is reduces and this causes the activity less concentrated and all sense of space enclosure is lost as a result of a more open streets. The analysis showed that the ratio of width of street to height of enclosing buildings is critical for good street design while the quality of the enclosure was contributed by the presence of buildings that enclosed both sides of the street leading to the enclosed spaces. This encourages a more focused activity which then creates a street node and makes the street a vibrant public arena.

\section{Conclusion}

This paper examines the physical qualities and elements that contribute to the character of street in the royal town of Kuala Kangsar. It also highlights street characteristics and its significance in preserving the identity of one of the historic royal town in Malaysia. The physical elements that ultimately shape the quality of a street has a significant contribution to the character of the streets. The historical significance of traditional streets in the royal towns helps evoked a lot of meanings to the users thus influencing their degree of street characteristics. The research has established that attractiveness, visibility and human scale are physical qualities that should be consider in the design of street in royal towns due to its significant contribution in influencing the character of street. Elements such as building design, building skyline, building continuity and consistency, vertical elements, appearance of civic buildings, marker sequences, building scale and enclosure are 
associated with contributory factors such as location of building, function of building, building age, building size and height, building form, roof form, building length and openings, architectural style, façade design, building signage, five-foot walkway, street width and quality of view. It is discovered that the qualities of a street influenced the overall character of a town and that it gives an overall impression of a place. It is vital to note that character of street is associated with these elements and factors contributing towards it and thus must be assessed along this basis. It is the way each element responds to each other that determines the quality and the uniqueness of a street.

\section{Acknowledgements}

This work was supported by Universiti Kebangsaan Malaysia (UKM) under Grant Nos. FRGS/1/2015/SSI11/UKM/o2/2

\section{References}

Abbasiasbagha, A., Aflakib, A., Lamitc, H., Awadd, Z. A. C. M., \& Mahyuddine, N. "Achieving continuity and consistency in urban environments: the importance of building attributes and street elements".

Ab Rahman, Z., Thani, S. K. S. O., \& Roslan, R. (2019). "Identifying Characters of Good Street for Greater Urban Quality of Life". Asian Journal of Quality of Life, 4(15), 19-31.

Asif, N., Utaberta, N., \& Sarram, A. (2019). “Architectural Styles of Malaysian Mosque: Suitability In Compact Urban Settings”. In MATEC Web of Conferences (Vol. 266, p. o6oo1). EDP Sciences.

Carmona, M., Tiesdell, S., Heath, T., \& Oc, T. (2003). "Public Space Urban Space: The Dimension of Urban Design".

Compendium, U. D. (2007). “2: Delivering Quality Places”. English Partnerships/Housing Corporation.

De Carlo, G. (1990). “Streets as Landmarks”. Places, 6(2).

Desai, M. (2015). "Reforming complete streets: Considering the street as place (Doctoral dissertation, University of Cincinnati)".

Gehl, J. (2011). “Life Between Buildings: Using Public Space”. Island press.

Harun, N. Z., Fairuz, D. N., \& Nordin, N. A. (2015). "The roles of urban heritage in determining the image of the royal town of Sri Menanti, Negeri Sembilan”. Planning Malaysia Journal, 13(5).

Ja'afar N. H. (2014). "Karakter Fizikal Jalan Tradisional; Kajian Kes Di Melaka Bandaraya Bersejarah (Doctorate Thesis). Universiti Teknologi Malaysia, Skudai, Johor”.

Jacobs, A. B. (1993). Great Streets

Lubis, A. R., Wade, M., \& Khoo, S. N. (2010). Perak Postcards, 189os-1940s. Areca Books.

Local Plan Kuala Kangsar District (2020). Kuala Kangsar District Council

Mehta, V. (2007). "Lively streets: Determining environmental characteristics to support social behavior". Journal of planning education and research, 27(2), 165-187.

Moughtin, C., Oc, T., \& Tiesdell, S. (1999). “Urban design: ornament and decoration. Routledge”. 
Shamsuddin, S. (2011). “Townscape revisited: Unravelling the character of the historic townscape in Malaysia”. Penerbit UTM Press.

Selamat, N. H., \& Othman, H. (2016). "Chapter Three Image (Re) Presentation and Royal Tourism: A Case Study of The Royal City of Kuala Kangsar, Ipoh, Malaysia”. Tourism and Monarchy in Southeast Asia, 39 .

Samsudin, N. A., Rosley, M. S. F., Shahminan, R. N. R., \& Mohamad, S. (2018). "Preserving the Characteristics of Urban Heritage: An insight into the concept of Malaysian Royal Towns". Environment-Behaviour Proceedings Journal, 3(7), 277-283.

Shamsuddin, S. (1997). "Identity of Place: A Case Study of Kuantan Town Centre, Malaysia (Doctoral dissertation, University of Nottingham".

Shamsuddin, S., \& Ujang, N. (2008). "Making places: The role of attachment in creating the sense of place for traditional streets in Malaysia”. Habitat International, 32(3), 399-409.

Shamsuddin, S., \& Sulaiman, A. B. (2010). "The Street and Its Influence on The Sense of Place of Malaysian Cities".

Shukri, S. M., Wahab, M. H., Ibrahim, M. A., \& Rozaly, M. Z. (2017). "Sd 26-PhysicalCharacteristics of a Public Square in Malay Royal Town. Sustainable and Resilient Cities: The Way Forward”. 81.

Shukri, S. M., Wahab, M. H., Amat, R. C., Taib, I., \& Rozaly, M. Z. M. (2018). "Definition and Physical Attributes that Characterise Settings of Malay Royal Towns in Malaysia”. International Journal of Engineering \& Technology, 7(3.9), 55-58.

Sulaiman, A. B. (2000). "Urban Design Method-Theory and Practice: A Case Study in Malaysia, University of Nottingham, Nottingham (Doctoral dissertation, Ph. D. Thesis)”.

Sulaiman, A. B., Shamsuddin, S., Norbienna, S. L., Anwar, M., \& Awam, (2007). "J. K. Konsep Baru Model Bandaraya/Bandar Berasaskan Kepada Rekabentuk Bandar Tradisional”. 